\title{
Performance of Transplanted Pigeon Pea [Cajanus cajan (L) Millsp.] under Rainfed Condition of Northern Hill Zone of Chhattisgarh, Madhya Pradesh
}

\author{
K.P. Tiwari* and Namrata Jain \\ JNKVV, Krishi Vigyan Kendra, Umaria (M.P.)-484661, India \\ *Corresponding author
}

\begin{tabular}{l} 
K e y w o r d s \\
Pigeon pea, \\
Transplanting, SPI, \\
Technology gap, \\
Extension gap, \\
Technology index \\
\hline Article Info \\
\hline $\begin{array}{l}\text { Accepted: } \\
\text { 22 June 2020 } \\
\text { Available Online: } \\
\text { 10 July } 2020\end{array}$ \\
\hline
\end{tabular}

\section{A B S T R A C T}

Pigeon pea is an important pulse crop of Kharif season in Northern hill zone of chhattisgarh of Madhya Pradesh and primarily grown as rainfed. The productivity of crop is very low $(617 \mathrm{~kg} / \mathrm{ha})$ due to poor plant establishment method, moisture stress during vegetative and flowering stage and lack of awareness among farmers about the improved production technology. The region is also sensitive for frost. The present work was undertaken to evaluate the effect of system of pigeonpea intensification (SPI technology) on growth and yield of pigeonpea. For the purpose, Frontline demonstrations on SPI were conducted at 37 farmers field in three different villages during the year 2016-17 to 2018-19. The results of the study showed the mean highest yield of $25.85 \mathrm{q} / \mathrm{ha}$ by adopting transplanted SPI technology which produced 205.5 per cent higher seed yield over the farmers practice $(8.46 \mathrm{q} / \mathrm{ha})$. The average of three years data revealed that technology gap, extension gap and technology index were also noticed as $4.15 \mathrm{q} / \mathrm{ha}, 17.39 \mathrm{q} / \mathrm{ha}$ and 13.83 per cent, respectively. The highest average net profit of Rs. 83681/ha was obtained under transplanted Pigeon pea where as it was only Rs.19403/ha under farmers practice. The cost benefit ratio was found 3.95 and 2.08 under SPI and farmers practice respectively.

\section{Introduction}

Pigeon pea [Cajanus cajan (L) Millsp.], commonly known as Arhar or Tur or Redgram, is a pulse crop, predominantly grown during the Kharif season under wide range of agro ecological situations as rainfed crop in various cropping systems including intercropping. India is the largest producer, consumer and importer of pigeon pea in the world. India occupies $90 \%$ of the worlds pigeon pea area (48.61 lakh ha) and $80 \%$ of the world production. Madhya Pradesh occupies an area of about 5.79 lakh ha with production of 6.44 lakh tonnes with an average productivity of $1105 \mathrm{~kg} / \mathrm{ha}$. Tribal district Umaria of Northern hill zone of Chattisgarh occupies 14000 ha of pigeon pea with production and average productivity of 9000 tonnes and $617 \mathrm{~kg} / \mathrm{ha}$, respectively 
(Anonymous, 2015-16). The productivity of pigeonpea is quiet low due to influence by a number of biotic and abiotic factors. Maintaining adequate population for crop productivity in presence of abiotic and biotic stresses pose a major challenge needs to be tackled up by improved technologies for its cultivation. In rainfed area, rainfall is not only scanty but also erratic. Thus, the soil moisture become the most limiting factor in Pigeon pea production especially in the region of having light undulating sandy soil with poor fertility status. Soil moisture related limitation is the major constraint to higher productivity of pigeonpea with climatic aberrations experienced by the crop which is not conducive for its growth and development (Praharaj et al., 2015). The time of sowing has a predominant influence on both vegetative and reproductive growth phases of Pigeon pea. In order to ensure timely sowing under delayed onset of monsoon, to avoid weeds-crop competition in early vegetative growth stage, frost and also for better development of root, shoot and fruiting system, transplanting of Pigeon pea seedlings will be one of the better innovative agronomic idea.

SPI technology involves raising of seedlings in poly bags or direct in the polythene sheet based seed bed in nursery for a period of one month, then transplanting in main field immediately after soil wetting rains. SPI is a agro-ecological innovation for improving productivity, food security and resilience to the climate changes based on following principles i.e. early, quick and healthy plant establishment, reduced plant density, improve soil condition through organic matter with biofertilizer and utilization of conserve moisture for better development of root system. Therefore, the ransplanted Pigeon pea demonstration work was conducted by Krishi Vigyan Kendra, Umaria (M.P.) during 201615 to 2018-19.

\section{Materials and Methods}

The frontline demonstrations were conducted on 37 farmer's field in Ghulghuli, Tali and Chandiya villages of Umaria to demonstrate the performance of transplanted pigeon pea as compared to direct sowing which was practiced by the farmers at onset of monsoon during 2016-17 to 2018-19. Performance was assessed on the basis of the vegetative and reproductive characters of plants alongwith economical analysis. Demonstration trials on system of pigeonpea intensification was laid out on 0.4 ha area and adjacent 0.4 ha area was considered as control trial (Direct seeded). In both the fields, variety TJT-501 was sown, but practices followed under SPI system were different from existing farmers practice. The gap between existing farmers practice and demonstrated technology is given in Table 1.

The observations on vegetative and reproductive parameters i.e. Plant height, number of branches per plant, number of pods per plant, root nodules/plant, seed weight per plant and 100-seed weight were recorded from randomly selected plants under SPI and farmers practice and then the seed yield was converted in to quintals per hectare. Based on the recorded data, the following indices were worked out-

\section{Technology gap}

The technology gap is the difference between potential yield and yield of demonstrated technology plot and it was worked out by using the following formula-

Technology gap $=$ Potential yield Demonstration yield

\section{Yield extension gap}

The extension gap means the difference between demonstrated plot and farmers 
practices, which is calculated by the formula given below-

Yield Extension gap = Demonstration yieldFarmers yield

\section{Technology index (\%)}

Technology index measures the feasibility of evolved technology in the farmer's field and indicates that lower the value of technology index, higher is the feasibility of improved technology. It is calculated by the following formula-

Technology index $(\%)=($ Potential yield Demo yield)/ Potential yield x 100

\section{Results and Discussion}

The effect of system of pigeonpea intensification and farmers practice on growth and yield of pigeonpea is given in Table 2 and Table 3.

\section{Growth parameters}

\section{Plant height, branches and root nodules/plant}

The observation on plant height $(184.3 \mathrm{~cm})$, number of branches per plant (14.5) and root nodules/plant was higher (670.2) in SPI practice as compared to farmer's practice of direct seeding i.e. $159 \mathrm{~cm}, 5.1$ per plant and 83.9 over three years, respectively. It may be due to better development of root and shoot system by using solar and natural energy under SPI. Similar findings were also reported by Pradhan et al., (2014) and Jamadar et al., (2014).

\section{Yield attributes and yield}

Effect of transplanted pigeon pea and farmers practice on yield attributes and seed yield is presented in Table 2. Number of pods /plant
(2708), Seed yield per plant (382.6 g/plant) and test weight per 100 seed $(9.3 \mathrm{~g})$ was comparatively higher under transplanted planting of pigeonpea than farmers practice i.e. $\quad 257.3$ seeds/plant, $48.0 \mathrm{~g}$ seed weight/plant, $9.0 \mathrm{~g}$ test weight, respectively. It may be due to increased plant growth parameters which are known to have positive connection with seed yield and its attributes.

Average of the three years data revealed that seed yield (25.85 q/ha) and harvest index (19.91\%) was the highest under transplanted system of pigeonpea over farmers practice $(8.46 \mathrm{q} / \mathrm{ha}$ and $19.05 \%)$. That might be due to luxuriously utilizes sufficient light, moisture and nutrients under transplanted pigeon pea. These results are in accordance with the findings of Jamadar et al., (2014) and Pawan et al., (2011).

\section{Technology gap}

The technology gap means the difference between potential yield and yield of demonstrated technology plot. On an average of 3 years technology gap under demonstration of transplanted pigeon pea was $4.15 \mathrm{q} / \mathrm{ha}$. The technology gap observed may be attributed to dissimilarity in soil fertility status in different field conditions, crop production practices, micro farming situation, climate etc.

\section{Extension gap}

The extension gap means the difference between demonstrated plot and farmer's practices. On an average of three years (201617 to 2018-19) extension gap was 17.39 q/ha which emphasized the need to educate the farmers through various extension means like FLDs, trainings and other extension technique to revert the trend of wide extension gap. 


\section{Technology index}

Technology index indicates the feasibility of evolved technology in the farmer's field. Lower the value of technology index, higher is the feasibility of improved technology. The technology index of $13.83 \%$ based on average of three years data, shows the efficacy of good performance of technical intervention to increase the yield of pigeonpea. Findings of technology gap, extension gap and technology index are in accordance with Raju et al., (2016).

\section{Economic return}

Data in Table 4 indicated that net return, additional net return, and $\mathrm{B}: \mathrm{C}$ ratio of demonstrated technology of transplanted pigeonpea was Rs. 83681/ha, 64278/ha and 3.95 respectively as compared to farmers practice of direct seeding Rs.19403/ha, Rs. 64278/ha and 2.08. The highest net return of 117700/ha and Rs. 30400/ha were obtained under transplanting and farmers practice respectively during the year 2017-18. Similar findings were reported by Jamadar et al., (2014).

Table.1 Technological gap between transplanting method of Pigeon pea and existing farmer's practice

\begin{tabular}{|c|c|c|c|c|}
\hline S. No. & Technology & $\begin{array}{c}\text { Recommended Practice } \\
\text { (SPI) }\end{array}$ & $\begin{array}{l}\text { Farmers } \\
\text { Practice }\end{array}$ & Gap (\%) \\
\hline 1 & $\begin{array}{ll}\text { Variety } & \text { (Frost } \\
\text { escaping var.) }\end{array}$ & TJT-501 & TJT-501 & Nil \\
\hline 2 & Seed rate $(\mathrm{kg} / \mathrm{ha})$ & 1.5 & $12-15$ & $90 \%$ \\
\hline 3 & Sowing method & $\begin{array}{l}\text { Transplanting of } 30 \text { days } \\
\text { old seedling }\end{array}$ & Direct seeding & Full gap \\
\hline 4 & Time of sowing & 1 st week of June & $\begin{array}{l}1 \text { st week of } \\
\text { July }\end{array}$ & 30 days \\
\hline 5 & Seed treatment & $\begin{array}{l}\text { With Vitavex power @ } \\
2 \mathrm{~g} / \mathrm{kg} \text { of seed +PSB+ } \\
\text { Rhizobium + Trichoderma } \\
\text { @ } 10 \mathrm{~g} \text { each } / \mathrm{kg} \text { seed }\end{array}$ & $\begin{array}{ll}\text { No } & \text { seed } \\
\text { treatment } & \end{array}$ & Full gap \\
\hline 6 & $\begin{array}{l}\text { Soil treatment with } \\
\text { vermicompost } \\
\text { enriched } \\
\text { biofertilizer }\end{array}$ & $\begin{array}{ll}\text { PSB+ } & \text { Rhizobium } \\
+ \text { +Trichoderma } & @ \quad 5 \mathrm{~kg} / \mathrm{ha} \\
\text { each } & \end{array}$ & $\begin{array}{ll}\text { No } & \text { soil } \\
\text { treatment } & \end{array}$ & Partial gap \\
\hline 7 & Spacing $(\mathrm{cm})$ & $150 \times 90$ & $45 \times 20$ & $93.4 \%$ gap \\
\hline 8 & $\begin{array}{l}\text { Plant } \\
\text { (No/ha) }\end{array}$ & 7326 & 111000 & Partial gap \\
\hline 9 & $\begin{array}{l}\text { Fertilizer dose (NPK } \\
\mathrm{kg} / \mathrm{ha} \text { ) }\end{array}$ & $20: 50: 20$ & $10: 25: 0$ & Partial gap \\
\hline 10 & FYM (T/ha) & $5 \mathrm{t} / \mathrm{ha}$ & $2 \mathrm{t} / \mathrm{ha}$ & Partial gap \\
\hline 11 & Nipping practice & $\begin{array}{l}\text { Two nipping at } 25 \text { and } 50 \\
\text { DAT }\end{array}$ & No nipping & Full gap \\
\hline 12 & Plant protection & Need based & Need based & Nil \\
\hline
\end{tabular}


Table.2 Performance of Pigeon pea under recommended practice for pigeonpea cultivation (SPI) and farmer's practice

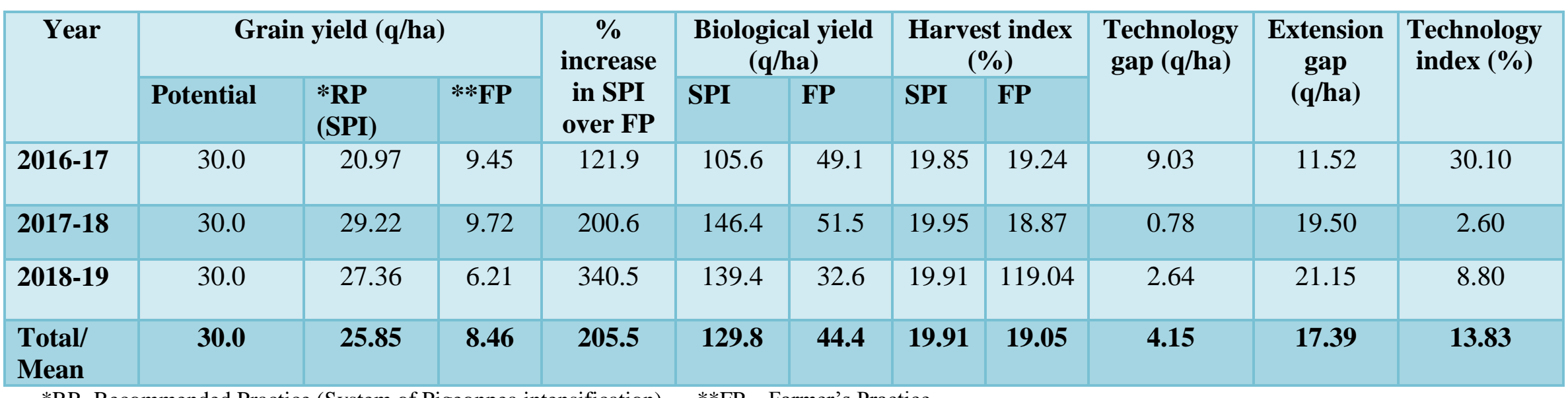

*RP- Recommended Practice (System of Pigeonpea intensification) $\quad$ **FP - Farmer's Practice

Table.3 Yield Parameters of pigeon pea under demonstration practice (SPI) and farmer's practice

\begin{tabular}{|c|c|c|c|c|c|c|c|c|c|c|c|c|}
\hline \multirow[t]{2}{*}{ Year } & \multicolumn{2}{|c|}{ Pods/plant (No) } & \multicolumn{2}{|c|}{ Seed/plant (g) } & \multicolumn{2}{|c|}{$\begin{array}{l}100 \text { seed weight } \\
\text { (g) }\end{array}$} & \multicolumn{2}{|c|}{$\begin{array}{c}\text { Root nodule/plant } \\
\text { (No) }\end{array}$} & \multicolumn{2}{|c|}{ Plant height (cm) } & \multicolumn{2}{|c|}{$\begin{array}{l}\text { Branches/ } \\
\text { Plant (No) }\end{array}$} \\
\hline & RP(SPI) & $\mathbf{F P}$ & $\mathbf{R P}(\mathrm{SPI})$ & FP & RP(SPI) & $\mathbf{F P}$ & RP(SPI) & FP & $\mathbf{R P}(\mathbf{S P I})$ & FP & RP(SPI) & $\mathbf{F P}$ \\
\hline 2016-17 & 2133 & 226 & 343 & 48.0 & 9.4 & 9.1 & 655.0 & 82.4 & 191.3 & 166.9 & 15.2 & 5.5 \\
\hline 2017-18 & 3052 & 283 & 410 & 53.0 & 9.3 & 8.9 & 683.2 & 91.0 & 175.0 & 160.0 & 14.8 & 5.0 \\
\hline 2018-19 & 2950 & 263 & 395 & 43.0 & 9.3 & 9.0 & 672.4 & 78.3 & 186.7 & 152.9 & 13.5 & 4.8 \\
\hline Mean & 2708 & 257 & 383 & 48.0 & 9.3 & 9.0 & 670.2 & 83.9 & 184.3 & 159.9 & 14.5 & 5.1 \\
\hline
\end{tabular}


Table.4 Economics of trial in Pigeon pea under demonstration (SPI) and farmer's practice

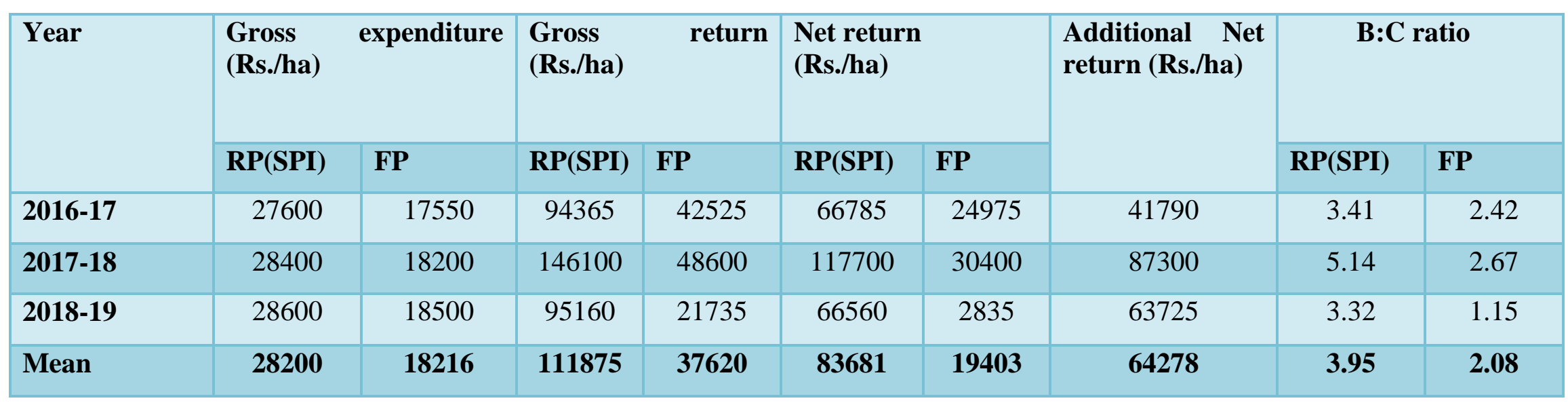


The significant change in economic parameter are due to the high seed yield per ha and also higher market prices that is result of transplanting because transplanted seedlings are well in advanced healthy stage of development and they switch over early to reproductive phase as compared to the normal sowing sown plots (Direct seeding during onset of monsoon) and also early harvest produce fetched good market prices because of less supply and high demand.

It is concluded from the study that a wide gap exists between potential and assessed transplanted pigeon pea yield mainly due to technology extension gap and lack of awareness about new technology. Assessment trial produced a significant positive result, created awareness and motivated the other farmers and extension workers to adopt suitable production technology of pigeon pea in the region.

\section{References}

Anonymous 2015-16. Districtwise area, production and yield (2011-12 to 201516). http://mpkrishi.mp.gov.in.

Jamadar MI, Sajjan AS and Kumar S. (2014). Economic analysis of seed production in transplanted pigeon pea. International Journal of Commerce and Business Management. 7(1): 63-66.

Pawan AS, Naglikar UP, Pujari BT and Halepyati AS. (2011). Influence of planting geometry on growth characters, seed and economics of transplanted pigeon pea. Karnataka Journal of Agricultural Sciences. 24 (3): 390-392.

Raju G, Teggelli S, Suresh SM and Zaheer Ahmed B. (2016). Improvement in productivity of pigeon pea through innovative production technology. International Journal of Science and Nature. 7(3): 601-603

Pradhan A, Thakur A, Sao A and Pachauri DP (2014). A new planting technique of Arhar for high production under rainfed condition. International Journal of Current Microbiology and Applied Sciences. 3(1): 666-669.

Praharaj CS, Kumar N, Singh Ummed, Singh SS and Singh Jagdish (2015). Transplanting in pigeonpea-A contingency measure for realizing higher productivity in Eastern Plains of India. Journal of Food Legumes 28(1): 34-39.

\section{How to cite this article:}

Tiwari, K.P. and Namrata Jain. 2020. Performance of Transplanted Pigeon Pea [Cajanus cajan (L) Millsp.] under Rainfed Condition of Northern Hill Zone of Chhattisgarh, Madhya Pradesh. Int.J.Curr.Microbiol.App.Sci. 9(07): 3100-3106. doi: https://doi.org/10.20546/ijcmas.2020.907.365 